\title{
Comparative characteristics of ethapolan and xanthan exopolysaccharides as agents for the increasing secondary oil extraction
}

\section{Mykola Ivakhniuk, Tetyana Pirog}

\section{National university of food technologies, Kyiv, Ukraine}

Keywords:

Acinetobacter sp.

IMV B-7005

Xanthomonas

campestris

Exopolysaccharide

Cultivation

Oil

\section{Article history:}

Received 26.03.2018

Received in revised form 03.06.2018

Accepted 29.06.2018

Corresponding author:

Mykola Ivakhniuk

E-mail:

Ivahniuk@ukr.net

DOI: $10.24263 / 2310-$

1008-2018-6-1-9

\section{Abstract}

Introduction. The purpose of research - to compare the cost of nutrient mediums for obtaining culture fluids of Acinetobacter sp. IMB B-7005 and Xanthomonas campestris strains (xanthan gum producers) for its using in the secondary oil extraction.

Materials and methods. Calculation of the culture fluid amount and the cost of nutrients for the ethapolan (producer Acinetobacter sp. IMB B-7005) and xanthan (producers of Xanthomonas campestris strains) exopolysaccharides production as oil extraction agents for 262 oil wells of Oil and Gas Production Administration "Okhtyrkanaftogas" of JSC "Ukrnafta" was carried out taking into account the following parameters: 4 times treatment per year of wells with the $15 \mathrm{~m}^{3}$ of EPS solution with its concentration $0,05 \%$ ).

Results and discussions. On the basis of the data on the concentration of synthesized polysaccharides by strainsproducer, the annual need for a culture fluid $\left(545-1849 \mathrm{~m}^{3}\right)$ was calculated for the treatment of wells of the OGPA "Okhtyrkanaftogas" and the amount of product per fermentation cycle according to selected technologies.

Theoretical calculations have shown that costs for the nutrient medium preparing for Acinetobacter sp. IMB B-7005 culture fluid obtaining on waste sunflower oil after frying meat, necessary for increasing secondary oil extraction at "Okhtyrkanaftogas" wells in 1.8-5.4 times less than in the case of ethapolan obtaining on $\mathrm{C}_{2}-\mathrm{C}_{6}$ substrates, molasses or their mixtures.

Comparison of nutrient medium cost for the preparation of ethapolan and the most famous polysaccharide xanthan obtained on molasses on technical glycerine was made. The cost of polysaccharide xanthan obtaining (in amount that would provide oil extraction in equivalent quantity like in case of ethapolan using) in 12.7-16.7 times higher compared to the ethapolan obtaining.

Conclusion. Obtained results confirm the economic feasibility of the ethapolan synthesis on waste oil for the polysaccharide using in secondary oil production in comparison with the technologies for xanthan obtaining. 


\section{Introduction}

The main part of the oil fields in Ukraine is now entering the final stage of development, characterized by high watering of extracted petroleum and falling rates of production. The development of oil deposits is maintained by sustentation of reservoir pressure by injected in it water, which leads to regular wells watering, a sharp decline of oil yields and, as a consequence, stopping of such wells. The course of this process is connected, first of all, with the inhomogeneity of the collector in terms of permeability, porosity, presence of cracks, both technogenic and natural origin. It should be noted that the residual oil reserves are concentrated in the impermeable part of the collector [1].

Existing methods (pump, compressor, fountain) of oil production are imperfect, as they allow to get $40-60 \%$ of geological oil reserves. That is why polymers of high viscosity are widely used in the oil industry [1-3].

As a result of many years of researches (from the 1960's) and industrial testing of polymers in the intensification of oil production, a number of requirements have been formed to it [2-4]: rapid and complete solubility in water, stability of physico-chemical properties of the polymer in time and under temperature influence, resistance to salts in reservoir waters, effective increase of water viscosity at low concentrations.

In comparison with synthetic polymers, exopolysaccharides (EPS) of microbial origin have a number of significant advantages, including those that allow them to be used in very harsh conditions, where synthetic polymers using is ineffective [3]. Thus, EPS are stable at temperature range of $100-120^{\circ} \mathrm{C}$, and some retain their properties even at $150{ }^{\circ} \mathrm{C}$, which is corresponds to the temperature range of the oil deposits. EPS are stable in a wide range of $\mathrm{pH}$, both in acidic and alkaline environments. The benefit of microbial polysaccharides, compared with other reagents, can be their safety for both humans and the environment [3].

Despite a number of attractive properties of microbial polysaccharides, there are some factors that inhibit their industrial production. Currently, the cost of polysaccharides of microbial origin is still high, which is due to the high costs of biosynthesis and product allocation. Therefore, studies aimed to solve these problems are among the main in biotechnology of the EPS.

Domestic polysaccharide of multifunctional purpose - ethapolan (producer Acinetobacter sp. IMB B-7005) complies with the abovementioned requirements, in addition, using pilot-industrial series of culture fluid containing ethapolan for secondary oil extraction at the production oil wells of PJSC "Bashneft" had shown obtaining of additional 240 tons of oil under applying 1 ton of ethapolan [5].

This exopolysaccharide has several advantages over other EPSs, including the most famous polysaccharide xanthan (producer Xanthomonas campestris) [5]: higher viscosity of aqueous solutions, increasing viscosity in the presence of single- and bivalent cations, in the system $\mathrm{Cu}^{2+}$ glycine and at low $\mathrm{pH}$ values, a significant increase of viscosity in zones of low shear rates, ethapolan can stabilize emulsions of water with oil and other hydrocarbons due to the presence of a lipophilic part in its molecule.

The purpose of the research - to compare the cost of nutrient mediums for obtaining culture fluids of Acinetobacter sp. IMB B-7005 and X.campestris strains (xanthan gum producers) for its using in the secondary oil extraction.

\section{Materials and methods}

For a comparative assessment of the effectiveness of using polysaccharides ethapolan (producer Acinetobacter sp. IMV B-7005) and xanthan (strains-producers $X$. campestris MTCC 2286 [6], X. campestris 2103 [7]) for secondary oil extraction, the cost of nutrients was compared according to different technologies for obtaining these biopolymers. 


\section{- Microbiology, Biotechnology -}

Calculation of the amount of EPS-containing culture fluid was carried out for the Oil and Gas Production Administration "Okhtyrkanaftogas" of JSC "Ukrnafta", which owns 262 oil wells in its fund [http://www.rada.com.ua/rus /catalog/8205] on the basis of the technology of microbial polysaccharides using in the oil production, described in the patent "The method of isolation of the formation water inflow" (USSR Pat. No. 1726732A1SU). According to the patent for the intensification of secondary oil extraction for one oil well, solution of culture fluid with a concentration of EPS not less than $0,05 \%$ (mass fraction of carbohydrates), the volume of which is $15 \mathrm{~m}^{3}$, is using.

\section{Technologies of ethapolan and xanthan obtaining}

Technologies of ethapolan obtaining are shown in Table 1.

\section{Calculation of culture fluid amount}

Based on the concentration data of the synthesized polysaccharides given in Tables 1 and 2 and patent No. 1726732A1 SU data, the annual amount of culture fluid required for the treatment of 262 wells of "Okhtyrkanaftogas" was calculated. formula:

Calculation of the annual amount of culture fluid (G) was carried out according to the

$$
\mathrm{G}=15000 \times 0.5 \times 262 \times 4 / \mathrm{X}_{\mathrm{EPS}} \times 1000 \mathrm{~m}^{3}
$$

where 15000 - required amount of culture fluid solution for processing one oil well in accordance with the patent №1726732A1 SU, 1; 0.5 - concentration of polysaccharide solution, g/l; - quantity of oil wells of "Okhtyrkanaftogas", pcs; 4 - number of wells processing per year; $\mathrm{X}_{\mathrm{EPS}}$ concentration of polysaccharide in a culture fluid, $\mathrm{g} / \mathrm{l} ;-$ coefficient of liters conversion into $\mathrm{m}^{3}$;

Taking into account the total losses, the annual amount of post-fermentation fluid ( $\left.\mathbf{G}_{\text {an }}\right)$ was calculated according to the formula:

$$
\mathrm{G}_{\mathrm{an}}=\mathrm{G} /(1-0.3+0.1) \quad \mathrm{m}^{3}
$$

where 0.3 - losses of the target product during biosynthesis;

0.1 - possible cases of non-sterile fermentation process.

Calculation of the culture fluid amount per cycle of fermentation (Gcyc) was carried out according to the formula:

$$
\mathrm{Gcyc}=\mathrm{G}_{\mathrm{an}} \times \mathrm{Tcyc} / \mathrm{W} \times 24 \quad \mathrm{~m}^{3}
$$

where $\mathrm{W}$ - number of working days per year (300 days); Tcyc - the cycle of the fermenter, which includes the time of basic fermentation $(30 \mathrm{~h})$ and the time of fermenter preparation to work (10 h).

On the basis of Gcyc, the number of stages of inoculum preparation $(\mathrm{N})$ :

$$
\mathrm{N}=\text { Gcyc } \times \mathrm{n}
$$

where $\mathrm{n}$-amount of inoculum, given in the notes of Tables 1 and 2 for every technology.

At the next stage, the cost of the nutrient medium was calculated, in order to obtain the culture fluid for the fermentation cycle, taking into account the costs of the inoculum receiving.

The prices (for the period of November 2017) of the mediums components in accordance with the catalog «Tehnohmya» [https://tehnohmya.uaprom.net], «Promkin» [https://zp.prom.ua/ua/c 2353605-fop-promkin.html] and site [https://flagma.ua] were used for calculations.

According to the literature $[6,7]$, mediums which are shown in Table 2 were used for X.campestris cultivation. 
Characteristics of ethapolan obtaining technologies

\begin{tabular}{|c|c|c|c|c|c|c|}
\hline \multirow[b]{2}{*}{ 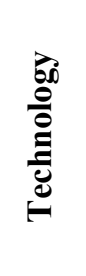 } & \multirow{2}{*}{ 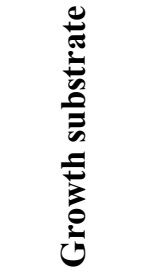 } & \multicolumn{2}{|c|}{$\begin{array}{l}\text { Concentration (\%) } \\
\text { of carbon source for }\end{array}$} & \multirow[b]{2}{*}{ Mineral salts, g/l } & \multirow{2}{*}{ 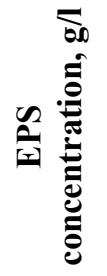 } & \multirow{2}{*}{ } \\
\hline & & 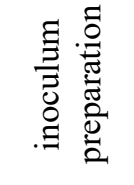 & 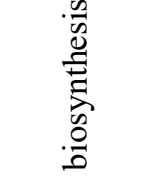 & & & \\
\hline \multirow{6}{*}{$\begin{array}{c}\text { №1 } \\
\text { basic }\end{array}$} & \multirow{6}{*}{ ethanol } & \multirow{6}{*}{1.0} & \multirow{6}{*}{1.0} & $\mathrm{KH}_{2} \mathrm{PO}_{4}-6.8$ & \multirow{6}{*}{4.25} & \multirow{6}{*}{ [8] } \\
\hline & & & & KOH-1.8 & & \\
\hline & & & & KCI-1.4 & & \\
\hline & & & & $\mathrm{NH}_{4} \mathrm{NO}_{3}-0.6$ & & \\
\hline & & & & $\mathrm{MgSO}_{4}-0.4 \times 7 \mathrm{H}_{2} \mathrm{O}$ & & \\
\hline & & & & yeast autolysate -0.25 & & \\
\hline \multirow{6}{*}{ №2 } & \multirow{6}{*}{$\begin{array}{l}\text { ethanol+ } \\
\text { glucose }\end{array}$} & \multirow{6}{*}{$\begin{array}{l}\text { ethanol, } \\
0.5\end{array}$} & \multirow{6}{*}{$\begin{array}{c}\text { ethanol, } \\
0.75+ \\
\text { glucose, } \\
0.75\end{array}$} & $\mathrm{KH}_{2} \mathrm{PO}_{4}-6.8$ & \multirow{6}{*}{8.3} & \multirow{6}{*}{ [9] } \\
\hline & & & & KOH-1.8 & & \\
\hline & & & & $\mathrm{NH}_{4} \mathrm{NO}_{3}-0.6$ & & \\
\hline & & & & KCI-1.4 & & \\
\hline & & & & $\mathrm{MgSO}_{4}-0.4 \times 7 \mathrm{H}_{2} \mathrm{O}$ & & \\
\hline & & & & yeast autolysate -0.25 & & \\
\hline \multirow{4}{*}{ №3 } & \multirow{4}{*}{$\begin{array}{l}\text { ethanol+ } \\
\text { molasses }\end{array}$} & \multirow{4}{*}{$\begin{array}{l}\text { ethanol, } \\
0.5\end{array}$} & \multirow{4}{*}{$\begin{array}{c}\text { ethanol, } \\
0.75+ \\
\text { molasses, } \\
0.75\end{array}$} & $\mathrm{KH}_{2} \mathrm{PO}_{4}-3.4$ & \multirow{4}{*}{8.35} & \multirow{4}{*}{ [10] } \\
\hline & & & & KOH-0.9 & & \\
\hline & & & & $\mathrm{MgSO}_{4}-0.4 \times 7 \mathrm{H}_{2} \mathrm{O}$ & & \\
\hline & & & & yeast autolysate -0.25 & & \\
\hline \multirow[b]{3}{*}{ №4 } & \multirow{3}{*}{$\begin{array}{l}\text { sodium } \\
\text { acetate }+ \\
\text { molasses }\end{array}$} & \multirow{3}{*}{$\begin{array}{c}\text { sodium } \\
\text { acetate, } \\
0.7\end{array}$} & \multirow{3}{*}{$\begin{array}{c}\text { sodium } \\
\text { acetate, } \\
1.1+ \\
\text { molasses, } \\
0.75\end{array}$} & $\mathrm{KH}_{2} \mathrm{PO}_{4}-2.0$ & \multirow[b]{3}{*}{9.7} & \multirow[b]{3}{*}{ [11] } \\
\hline & & & & $\mathrm{MgSO}_{4}-0.4 \times 7 \mathrm{H}_{2} \mathrm{O}$ & & \\
\hline & & & & yeast autolysate -0.25 & & \\
\hline \multirow{4}{*}{ №5 } & \multirow{4}{*}{ waste oil } & \multirow{4}{*}{$\begin{array}{l}\text { refined } \\
\text { oil, } 0.5\end{array}$} & & $\mathrm{KH}_{2} \mathrm{PO}_{4}-6.8$ & & \\
\hline & & & & $\mathrm{KOH}-0.9$ & & \\
\hline & & & $\begin{array}{l}50 \\
\text { waste }\end{array}$ & $\mathrm{NH}_{4} \mathrm{NO}_{3}-0.6$ & 14.4 & [12] \\
\hline & & & & $\frac{\mathrm{MgSO}_{4}-0.4 \times 7 \mathrm{H}_{2} \mathrm{O}}{\text { veast autolvate }-0.25}$ & & \\
\hline
\end{tabular}

Notes: 1. Mediums according to technologies № 1-5 also contained macro-elements (g/l): $\mathrm{CaCl}_{2} \times 2 \mathrm{H}_{2} \mathrm{O}-0.1 ; \mathrm{FeSO}_{4} \times 7 \mathrm{H}_{2} \mathrm{O}-0.001$, the cost of which was not taken into account because of their insignificant amount.

2. In mediums № 1-4, $0.0006 \%$ of pantothenate was used as a growth factor and in medium № 5 - multivitamin preparation "Complevit" (0.00095\%, in recount to calcium pantothenate).

3. Hydrolysed molasses were used in mediums № 3 and 4, $\left(20 \mathrm{ml}\right.$ of $1 \mathrm{~N} \mathrm{H}_{2} \mathrm{SO}_{4}$ were added to $100 \mathrm{~g}$ of molasses).

4. Quantity of inoculum for technologies № 1,2 is $5 \%$, for technologies № $3-5-10 \%$. 
Characteristics of xanthan obtaining technologies

\begin{tabular}{|c|c|c|c|c|c|}
\hline \multirow{2}{*}{$\begin{array}{c}\text { Techno- } \\
\operatorname{logy}\end{array}$} & \multirow[b]{2}{*}{ Producer } & \multicolumn{2}{|c|}{ Medium for } & \multirow{2}{*}{$\begin{array}{c}\text { EPS } \\
\text { concentration, } \\
\text { g/l } \\
\end{array}$} & \multirow[b]{2}{*}{ References } \\
\hline & & $\begin{array}{c}\text { inoculum } \\
\text { preparation }\end{array}$ & biosynthesis & & \\
\hline I & $\begin{array}{c}\text { X.campestris } \\
\text { MTCC } \\
2286\end{array}$ & $\begin{array}{l}\text { molasses, } 1 \% \text {; } \\
\mathrm{K}_{2} \mathrm{HPO}_{4}, 2 \mathrm{~g} / 1 ; \\
\text { Tween } 80,0.3 \\
\mathrm{~g} / 1\end{array}$ & $\begin{array}{l}\text { molasses, } 10 \\
\mathrm{~g} / \mathrm{l} ; \\
\text { yeast extract, } 10 \\
\mathrm{~g} / \mathrm{l} ; \\
\mathrm{K}_{2} \mathrm{HPO}_{4}, 2 \mathrm{~g} / 1 ; \\
\text { Tween } 80,0.3 \\
\mathrm{~g} / \mathrm{l} ; \\
\mathrm{MgSO}_{4} \times 7 \mathrm{H}_{2} \mathrm{O}, \\
0.1 \mathrm{~g} / 1\end{array}$ & 12.3 & [6] \\
\hline II & $\begin{array}{c}\text { X.campestris } \\
2103\end{array}$ & $\begin{array}{l}\text { glucose, } 1.0 \% \text {; } \\
\text { yeast extract, } \\
0.3 \% \text {; } \\
\text { malt extract, } \\
0.3 \% \text {; } \\
\text { pepton, } 0.5 \%\end{array}$ & $\begin{array}{l}\text { crude glycerin, } \\
2 \% \text {; } \\
\text { urea, } 0.01 \% \text {; } \\
\mathrm{KH}_{2} \mathrm{PO}_{4}, 0.1 \%\end{array}$ & 7.2 & [7] \\
\hline
\end{tabular}

Notes:

1. Hydrolysed molasses were used in mediums I ( $10 \mathrm{ml}$ of $5 \mathrm{~N} \mathrm{H}_{2} \mathrm{SO}_{4}$ were added to $200 \mathrm{ml}$ molasses, after which mixture was stirred and sparged with air for 15 minutes).

2. Quantity of inoculum for technology I is $5 \%$, for technology II $-10 \%$.

\section{Results and discussions}

\section{Analysis of various technologies of ethapolan obtaining}

A number of technologies have been developed for the EPS ethapolan production (see Table 1), each of which has its advantages and disadvantages. Thus, in particular, in technology № 1 (basic technology) [8] ethanol is used as a carbon source. This technology was developed in the late 80's and early 90's of the XX century, when using of such substrate was expedient, since in the former USSR it was popular to use non-food raw materials (methanol, ethanol, ethylene glycol, etc.) through their low cost. But the situation has changed and every year the cost of ethanol is increasing. Thus, in 2015 state enterprise "Ukrspirt" raised the price of the ethyl alcohol of luxury class for decalitre from 175 to 265 UAH, and since April 2016 the price was increased by another 19\% [https: //www.kmu. gov.ua/ua/news/247982137?=print], respectively, such a sharp price change complicates implementation of ethapolan technology production on ethanol.

One of the approaches to intensify synthesis of microbial polysaccharides is using of growth substrates mixture. Under simultaneous consumption of substrates mixture by microorganisms, increasing of biomass and the target product quantities, the growth rate and the reduction of the lag phase length were observed [13]. Technology № 2 involves synthesis of $8.3 \mathrm{~g} / 1$ of ethapolan in a mixture of ethanol and glucose [9]. Compared to the basic technology, the quantity of synthesized ethapolan is 2 times higher, but the disadvantages of this technology are high cost of both substrates, as well as the risk of glucose contamination.

Wastes from sugar production (molasses and sugar syrup) are widely used in the industrial production of polysaccharides [14]. Technology № 3 [10] envisages using of 


\section{- Microbiology, Biotechnology -}

ethanol and molasses mixture as a source of carbon and energy. In addition, the salt content in the medium is almost 4 times lower than in the basic one. The advantage of this technology, in comparison with technologies № 1 and 2, is the low cost of molasses and no need of an additional source of nitrogen feed, since molasses contain about $1.1 \%$ of organic nitrogen [10]. However, on the other hand, this substrate can be a source of contamination, since it contains carbohydrates.

A possible solution of the problem of ethanol high cost is its replacement with sodium acetate (Technology № 4 [11]). The medium for ethapolan obtaining, which contains a mixture of sodium acetate and molasses, is cheaper compared to the basic one. It should be noted that molasses according to technologies 3 and 4 require hydrolysis, which requires additional costs and time $[10,11]$.

Despite the availability and low cost of molasses, this technology has some disadvantages: 1) high risk of contamination; 2) the need for using antifoaming agent (since foaming occurs under molasses mixing); 3 ) the presence in molasses composition of possible inhibitors of microorganisms growth (betaine, metal cations) [13].

The advantage of technology № 5 is using waste sunflower oil as a substrate for the EPS synthesis. It should be noted that besides affordability and low cost, this substrate does not require sterilization and may contain additional growth factors that have gone from food during frying [12]. However, depending on the multiplicity of oil using, it may contain toxic impurities, which can be inhibitors of producer's growth and target product synthesis.

Note, that technologies 1-4 envisage using of $0.0006 \%$ of pantothenate calcium, according to which the strain IMV B-7005 is auxotrophic. But in Ukraine there is no production of vitamin $\mathrm{B}_{5}$, therefore there is a need of expensive imported substance. In turn, technology №5 envisages using the multivitamin complex "Complevit" of Ukrainian production as a source of vitamin $\mathrm{B}_{5}$ [12].

The final data on the calculation of the ethapolan-containing culture fluid amount, which must be obtained during the fermentation cycle, are shown in Table 3.

Table 3

Data of the Acinetobacter sp. IMB B-7005 culture fluid amount calculation for secondary oil extraction

\begin{tabular}{|c|c|c|c|c|c|}
\hline Technology & $\begin{array}{c}\text { Concentration } \\
\text { of EPS, g/l }\end{array}$ & $\begin{array}{c}\text { Annual } \\
\text { quantity } \\
\text { of } \mathbf{C F} \\
\mathbf{( G )}, \mathbf{~ m}^{\mathbf{3}}\end{array}$ & $\begin{array}{c}\text { Annual } \\
\text { quantity of } \\
\text { CF with } \\
\text { taking into } \\
\text { account } \\
\text { losses (G) } \\
\mathbf{~ m}^{\mathbf{3}}\end{array}$ & $\begin{array}{c}\text { Quantity of } \\
\text { CF per } \\
\text { fermentation } \\
\text { cycle (Gcyc), } \\
\mathbf{m}^{\mathbf{3}}\end{array}$ & $\begin{array}{c}\text { Quantity } \\
\text { of } \\
\text { inoculum } \\
\text { production } \\
\text { cycles, pcs. }\end{array}$ \\
\hline №1 & 4.25 & 1849.4 & 3082.3 & 17.1 & 3 \\
\hline №2 & 8.3 & 946.4 & 1577.3 & 8.8 & 3 \\
\hline №3 & 8.35 & 941.3 & 1568.7 & 8.7 & 4 \\
\hline №4 & 9.7 & 810.3 & 1350.5 & 7.5 & 4 \\
\hline №5 & 14.4 & 545.8 & 909.7 & 5.1 & 4 \\
\hline
\end{tabular}

Note: CF - culture fluid 
Based on the data given in Tables 1 and 3, the cost of various nutrient mediums for the ethapolan preparation was calculated (Table 4).

Table 4

Composition and cost of nutrient mediums for various ethapolan production technologies

\begin{tabular}{|c|c|c|c|c|c|}
\hline $\begin{array}{c}\text { Techno- } \\
\operatorname{logy}\end{array}$ & $\begin{array}{c}\text { Components of } \\
\text { the nutrient } \\
\text { medium }\end{array}$ & $\begin{array}{c}\text { Price, } \\
\text { UAH/kg }\end{array}$ & $\begin{array}{c}\text { Quantity of } \\
\text { components, } \\
\text { kg }\end{array}$ & $\begin{array}{l}\text { Cost of the } \\
\text { component, } \\
\text { UAH }\end{array}$ & $\begin{array}{c}\text { Cost of } \\
\text { nutrient } \\
\text { medium, } \\
\text { UAH }\end{array}$ \\
\hline \multirow{7}{*}{$\begin{array}{c}\text { № } 1 \\
\text { Basic }\end{array}$} & ethanol $96 \%$ & 70.0 & 158.3 & 11081.8 & \multirow{7}{*}{18956} \\
\hline & $\mathrm{KH}_{2} \mathrm{PO}_{4}$ & 47.0 & 122.4 & 5752.8 & \\
\hline & $\mathrm{KOH}$ & 36.1 & 32.3 & 1166.0 & \\
\hline & KCI & 16.2 & 25.2 & 408.2 & \\
\hline & $\mathrm{NH}_{4} \mathrm{NO}_{3}$ & 12.6 & 10.8 & 136.1 & \\
\hline & $\mathrm{MgSO}_{4} \times 7 \mathrm{H}_{2} \mathrm{O}$ & 7.1 & 7.2 & 51.1 & \\
\hline & yeast autolysate & 80.0 & 4.5 & 360.0 & \\
\hline \multirow{8}{*}{ № 2} & ethanol $96 \%$ & 70.0 & 60.2 & 4214.0 & \multirow{8}{*}{10313.9} \\
\hline & glucose & 31.2 & 66.0 & 2059.2 & \\
\hline & $\mathrm{KH}_{2} \mathrm{PO}_{4}$ & 47.0 & 62.8 & 2951.6 & \\
\hline & $\mathrm{KOH}$ & 36.1 & 16.6 & 599.3 & \\
\hline & $\mathrm{NH}_{4} \mathrm{NO}_{3}$ & 12.6 & 5.6 & 70.6 & \\
\hline & KCI & 16.2 & 12.9 & 208.9 & \\
\hline & $\mathrm{MgSO}_{4} \times 7 \mathrm{H}_{2} \mathrm{O}$ & 7.1 & 3.7 & 26.3 & \\
\hline & yeast autolysate & 80.0 & 2.3 & 184.0 & \\
\hline \multirow{6}{*}{ № 3} & ethanol $96 \%$ & 70.0 & 56.1 & 3927.0 & \multirow{6}{*}{6422.9} \\
\hline & molasses & 3.5 & 130.5 & 416.8 & \\
\hline & $\mathrm{KH}_{2} \mathrm{PO}_{4}$ & 47.0 & 32.9 & 1546.3 & \\
\hline & $\mathrm{KOH}$ & 36.1 & 8.7 & 314.1 & \\
\hline & $\mathrm{MgSO}_{4} \times 7 \mathrm{H}_{2} \mathrm{O}$ & 7.1 & 3.8 & 26.9 & \\
\hline & yeast autolysate & 80.0 & 2.4 & 192.0 & \\
\hline \multirow{5}{*}{ № 4} & sodium acetate & 56.4 & 88.3 & 4980.1 & \multirow{5}{*}{6352.4} \\
\hline & molasses & 3.5 & 112.5 & 395.8 & \\
\hline & $\mathrm{KH}_{2} \mathrm{PO}_{4}$ & 47.0 & 16.7 & 784.9 & \\
\hline & $\mathrm{MgSO}_{4} \times 7 \mathrm{H}_{2} \mathrm{O}$ & 7.1 & 3.3 & 23.4 & \\
\hline & yeast autolysate & 80.0 & 2.1 & 168.0 & \\
\hline \multirow{7}{*}{ № 5} & waste sunflower oil & 5.38 & 237.1 & 1275.0 & \multirow{7}{*}{3535.6} \\
\hline & refined oil & 37.4 & 2.6 & 97.4 & \\
\hline & $\mathrm{KH}_{2} \mathrm{PO}_{4}$ & 47.0 & 38.5 & 1809.5 & \\
\hline & $\mathrm{KOH}$ & 36.1 & 5.1 & 184.1 & \\
\hline & $\mathrm{NH}_{4} \mathrm{NO}_{3}$ & 12.6 & 3.4 & 42.8 & \\
\hline & $\mathrm{MgSO}_{4} \times 7 \mathrm{H}_{2} \mathrm{O}$ & 7.1 & 2.2 & 15.6 & \\
\hline & yeast autolysate & 80.0 & 1.4 & 112.0 & \\
\hline
\end{tabular}




\section{- Microbiology, Biotechnology -}

Thus, data of the Table 4 show that the most effective and economically feasible is technology № 5. Costs for nutrient medium according to this technology are 55-80\% lower compared to others. In addition, the cost of the selected medium can be reduced by replacing the refined oil with the waste one for inoculum obtaining. Our latest research has demonstrated the ability of using oil of any quality and its mixtures, which makes it possible to develop a universal technology that is independent of the raw materials supplier [11]. Worth to notice that besides the economic benefits, using as a substrate of waste oil also has environmental benefits, since the emissions of oils to the environment are not regulated.

Accordingly, for the comparative evaluation of ethapolan and xanthan polysaccharides using effectiveness, technology №5 was considered as the main one.

\section{Analysis of technologies for xanthan production on industrial waste}

Xanthan is one of the most famous polysaccharides, the annual production of which is 30000 tons, which in the monetary equivalent is 408 million dollars USA and every year the need for it increases [14]. Note that, in general, hydrocarbon substrates (glucose, sucrose, starch) are used for xanthan gum obtaining $[15,16]$. But among the large number of technologies described in the literature, for the analysis, the technologies for this EPS obtaining on industrial waste were chosen, since the medium for ethapolan obtaining also contains waste oil.

It is worth noting that xanthan, unlike ethapolan, has no ability to increase the viscosity of the solution in the presence of copper salts, respectively, to obtain the required viscosity, culture fluid of xanthan should be used in 10 times more compared to ethapolan.

The generalized data of the X.campestris culture fluid needs are given in Table5.

Generalized data of calculation of

Table 5

X.campestris culture fluid as oil-pressuring agent

\begin{tabular}{|c|c|c|c|c|c|}
\hline $\begin{array}{c}\text { Techno- } \\
\operatorname{logy}\end{array}$ & $\begin{array}{c}\text { Concentration } \\
\text { of EPS, g/l }\end{array}$ & $\begin{array}{c}\text { Annual } \\
\text { quantity } \\
\text { of CF } \\
(\mathrm{G}), \mathrm{m}^{3}\end{array}$ & $\begin{array}{c}\text { Annual } \\
\text { quantity of CF } \\
\text { with taking } \\
\text { into account } \\
\text { losses }\left(\mathrm{G}_{\mathrm{an}}\right), \\
\mathrm{m}^{3}\end{array}$ & $\begin{array}{c}\text { Quantity of } \\
\text { CF per } \\
\text { fermentation } \\
\text { cycle } \\
(\mathrm{Gcyc}), \mathrm{m}^{3}\end{array}$ & $\begin{array}{c}\text { Quantity of } \\
\text { inoculum } \\
\text { production } \\
\text { cycles, pcs. }\end{array}$ \\
\hline I & 12.3 & 6390 & 10650 & 59 & 5 \\
\hline II & 7.2 & 10917 & 18194 & 101 & 5 \\
\hline
\end{tabular}

Note: $\mathrm{CF}$ - culture fluid

Based on the data given in Tables 2 and 5, the cost of various nutrient mediums for the xanthan preparation was calculated (Table 6). 
Composition and cost of mediums for the xanthan production on industrial waste

\begin{tabular}{|c|c|c|c|c|c|}
\hline $\begin{array}{c}\text { Techno- } \\
\operatorname{logy}\end{array}$ & $\begin{array}{c}\text { Components of } \\
\text { the nutrient } \\
\text { medium }\end{array}$ & $\begin{array}{c}\text { Price, } \\
\text { UAH/kg }\end{array}$ & $\begin{array}{c}\text { Quantity of } \\
\text { components, } \\
\text { kg } \\
\end{array}$ & $\begin{array}{c}\text { Cost of the } \\
\text { component, } \\
\text { UAH }\end{array}$ & $\begin{array}{c}\text { Cost of } \\
\text { medium, } \\
\text { UAH }\end{array}$ \\
\hline \multirow{5}{*}{ I } & molasses & 3.5 & 621.7 & 2175.9 & \multirow{5}{*}{58945.4} \\
\hline & yeast extract & 80.0 & 590.0 & 47200.0 & \\
\hline & $\mathrm{K}_{2} \mathrm{HPO}_{4}$ & 47.0 & 124.3 & 5842.1 & \\
\hline & Tween 80 & 195.0 & 18.9 & 3685.5 & \\
\hline & $\mathrm{MgSO}_{4} \times 7 \mathrm{H}_{2} \mathrm{O}$ & 7.1 & 5.9 & 41.9 & \\
\hline \multirow{6}{*}{ II } & crude glycerin & 14.2 & 2020.0 & 28684.0 & \multirow{6}{*}{44928.0} \\
\hline & glucose & 31.2 & 110.0 & 3422.0 & \\
\hline & yeast extract & 80.0 & 67.0 & 5360.0 & \\
\hline & pepton & 75.0 & 35.0 & 2625.0 & \\
\hline & $\mathrm{KH}_{2} \mathrm{PO}_{4}$ & 47.0 & 101.0 & 4747.0 & \\
\hline & urea & 9.0 & 10.0 & 90.0 & \\
\hline
\end{tabular}

Data in Table 6 indicate that technology of xanthan obtaining on crude glycerine is more effective. In addition, to date, the problem of crude glycerine utilization is much sharper than molasses, as annual biofuel production is increasing. It should be noted that for every 100 liters of biodiesel, almost 10 liters of crude glycerol (the so-called glycerol fraction) are forming [17].

Although the technology of xanthan production on glycerol is more effective than on molasses, but compared with technology №5, the cost of nutrient medium preparing for EPS obtaining (for secondary oil extraction) is 13 times higher. It is due to a significantly cheaper carbon source using, higher in twice EPS-synthesizing ability of Acinetobacter sp. IMB B7005 compared to the xanthan's producer, as well as lower costs of EPS-containing culture fluid for wells processing.

\section{Conclusions}

Consequently, theoretical calculations of the cost for preparing the nutrient medium for production of the Acinetobacter sp. IMB B-7005 culture fluid required for increasing secondary oil production at "Okhtyrkanaftogas" (262 units) is 3535.6 UAH, while for the well-known EPS xanthan (in the amount that will produce equivalent amount of oil) - 44928 UAH.

\section{References}

1. Iupov A.H., Sharifullin A.V. (2003), Polimerni ta vuhlevodnevi spoluky dlia pidvyshchennia naftoviddachi plastiv vysokoobvodnennykh, Naftove hospodarstvo, 6 , pp. 48-51.

2. Li Q., Kang C., Wang H., Liu C., Zhang C. (2002), Application of microbial enhanced oil recovery technique to Daqing Oilfield, Biochemical Engineering Journal, 11, pp 197-199. 


\section{- Microbiology, Biotechnology -}

3. Nazina T.N., Grigoryan A.A., Shestakova N.M., Babich T.L., Ivoilov V.S., Feng Q., et al. (2007), Microbiological investigations of high-temperature horizons of the Kongdian petroleum reservoir in connection with field trial of a biotechnology for enhanced oil recovery, Microbiology, 76, pp. 287-96.

4. Sen R. (2008), Biotechnology in petroleum recovery: The microbial EOR, Progress in Energy and Combustion Science, 34, pp. 714-724.

5. Pirog T.P., Korzh Yu.V. (2006), Etapolan - mikrobnyi ekzopolisakharyd multyfunktsionalnoho pryznachennia, Biopolimery i klityna, 22 (3), pp. 171-183

6. Murugesan A.G., Dhevahi B., Gowdhaman D., Bala Amutha K., Sathesh Prabu C. (2012), Production of xanthan employing Xanthomonas campestris using sugarcane molasses, Journal of Environmental Engineering, 2(2), pp. 31-34.

7. Brandão L.V., Assis D.J., López J.A., Espiridião M.C.A., Echevarria E.M., Druzian J.I. (2013), Bioconversion from crude glycerin by Xanthomonas campestris 2103: xanthan production and characterization, Brazilian Journal of Chemical Engineering, 30(4), pp. 737-746, DOI.org/10.1590/S0104-66322013000400006

8. Pirog T.P., Korzh Yu.V. (2006), Vliianie atsetata na sintez ekzopolisakharida etapolana pri kultivirovanii Acinetobacter sp. IMV B-7005 na srede s etanolom, Mikrobiologicheskii zhurnal, 68(5), pp. 12-20.

9. Pirog T.P., Kovalenko M.A., Kuz'minskaya Yu.V., Krishtab T.P. (2003), Intensification of synthesis of the exopolysaccharide ethapolan by Acinetobacter sp. $12 \mathrm{~S}$ grown on a mixture of substrates, Microbiology, 72(1) pp. 18-23. https://doi.org/10.1023/A:1022213703632

10. Pirog T.P., Lashchuk N.V., Zborovska B.M. (2007), Cyntez ekzopolisakharydu etapolanu v umovakh mikotrofnoho rostu Acinetobacter sp. IMV B-7005 na sumishi S2-spoluk i meliasy. Kharchova Promyslovist, 5, pp. 26-29.

11. Pirog T.P., Savchuk O.M., Muchnyk F.V. 2010, Intensyfikatsiia syntezu mikrobnoho polisakharydu etapolanu na sumishi atsetatu i meliasy, Kharchova promyslovist, 9 , pp. 52-54.

12. Ivakhniuk N.A., Voronenko A.A., Pirog T.P. (2017), Mikrobnyi sintez ekzopolisakharida etapolana na razlichnykh vidakh otrabotannykh rastitelnykh masel, Izvestiia Natsionalnoi akademii nauk Belarusi. Seriia biologicheskikh nauk, 2, pp. 87-93

13. Pidhors'kyy V.S., Iutyns'ka H.O., Pirog T.P. (2010), Intensyfikatsiya tekhnolohiy mikrobnoho syntezu, Naukova dumka, Kyiv.

14. Kalogiannis S., Iakovidou G., Liakopoulou-Kyriakides M., Kyriakidis D.A., Skaracis G.N. (2003), Optimization of xanthan gum production by Xanthomonas campestris grown in molasses, Process Biochemistry, 39, pp. 249-256, https://doi.org/10.1016/S0032-9592(03)00067-0

15. Nouha K., Kumar R.S., Balasubramanian S., Tyagi R.D. (2018), Critical review of EPS production, synthesis and composition for sludge flocculation, Journal Of Environmental Sciences-China, 66, pp. 225-245, DOI: 10.1016/j.jes.2017.05.020.

16. Felicia Katherine R., Muthukumaran C., Sharmila G., Manoj Kumar N., Tamilarasan K., Jaiganesh R. (2017), Xanthan gum production using jackfruit-seed-powder-based medium: optimization and characterization, 3 Biotech, 7(4), p. 248, DOI: 10.1007/s13205-017-0876-5

17. Pirog T.P., Grytsenko N.A., Sofilkanych A.P., Savenko I.V. (2015), Technologies of synthesis of organic substances by microorganisms using waste biodiesel production, Biotechnologia Acta, 8(3), pp. 9-27, DOI: 10.15407/ biotech8.03.009. 